\title{
Butyrophilin-Like Protein 2
}

National Cancer Institute

\section{Source}

National Cancer Institute. Butyrophilin-Like Protein 2. NCI Thesaurus. Code C113160.

Butyrophilin-like protein 2 ( $455 \mathrm{aa}, \sim 50 \mathrm{kDa}$ ) is encoded by the human BT NL2 gene. This protein plays a role in the inhibition of $\mathrm{T}$-cell proliferation. 